\section{UCDNN}

LIBRARY
University of Connecticut OpenCommons@UConn

Faculty Articles and Papers

School of Law

1973

\title{
The Development of European Regional Law of the Sea
}

Mark Weston Janis

University of Connecticut School of Law

Follow this and additional works at: https://opencommons.uconn.edu/law_papers

Part of the Admiralty Commons, and the European Law Commons

\section{Recommended Citation}

Janis, Mark Weston, "The Development of European Regional Law of the Sea" (1973). Faculty Articles and Papers. 98.

https://opencommons.uconn.edu/law_papers/98 


\section{HEINONLINE}

Citation: 1 Ocean Dev. \& Int'I L. J. 275 1973-1974

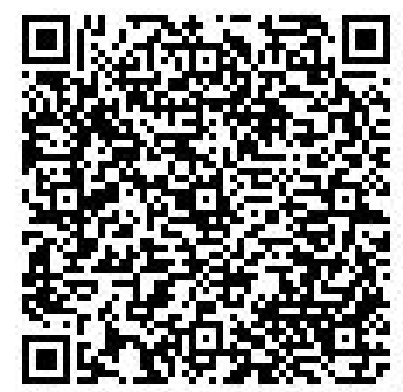

Content downloaded/printed from

HeinOnline (http://heinonline.org)

Tue Aug 16 12:52:39 2016

-- Your use of this HeinOnline PDF indicates your acceptance of HeinOnline's Terms and Conditions of the license agreement available at http://heinonline.org/HOL/License

-- The search text of this PDF is generated from uncorrected OCR text.

-- To obtain permission to use this article beyond the scope of your HeinOnline license, please use:

https://www.copyright.com/ccc/basicSearch.do?

\&operation $=$ go\&search $T y p e=0$

\&lastSearch $=$ simple\&all $=$ on \&titleOrStdNo $=0090-8320$ 


\title{
The Development of European Regional Law of the Sea
}

\author{
MARK W. JANIS*
}

\begin{abstract}
The development of regional law of the sea may be more practical than a new global order for the oceans and may be preferable to the extension of national maritime jurisdictions.

The Common Market has taken two important steps towards creating a European system of maritime law: The Common Fisheries Policy and the EEC Commission's decision of 10 September 1970 to apply the Common Market treaty to the continental shelf. The Common Fisheries Policy of 20 October 1970, opened national territorial waters within the EEC to all Community fishermen and provided the foundation for the generation of Common Market fishing policy. The continental shelf decision brought the exploration and exploitation of hydrocarbons on the shelf within EEC regulations and supervision.

The EEC has begun to co-ordinate European Law of the Sea negotiations for the Santiago Conference.

Other European organizations (the Bow Group, the Council of Europe, and the Western European Union) have proposed various non-EED regimes for maritime legislation and co-operation, but no such non-EEC proposal seems likely to be implemented. The future of European law of the sea lies with the Common Market which can make an important contribution to European maritime order and provide a model of regional co-operation for other areas of the globe.
\end{abstract}

*This paper was prepared for the Conference on Developments in the Law of the Sea, sponsored by the American Society of International Law and the Northwestern School of Law of Lewis and Clark College, Portland, Oregon, May 12, 1973.

The author is a graduate of Princeton and Oxford Universities with degrees in International Relations and Jurisprudence. He is a Lieutenant (jg), USNR, and is assigned to the faculty of the Naval Postgraduate School, Monterey, California, as an instructor in history and politics. This paper does not necessarily represent the views of the Naval Postgraduate School or of the United States Navy. The ideas expressed herein are only those of the author and all errors of fact and fancy are strictly attributable to him. He has however, greatly benefited by discussions with Dr. Robert L. Friedheim of the Center for Naval Analyses and with Professors Robert Von Pagenhardt and Donald C. Daniel of the Naval Postgraduate School. Helen C. Philos, Librarian of the American Society of International Law, was very helpful in his searches, and to her and the ASIL Library and the Washington, D.C., Library of the European Community, he owes many thanks.

XEAN DEVELOPMENT AND INTERNATIONAL LAW JOURNAL 1973, VOL. 1 NUMBER 3

Copyright 01973 by Crane, Russak \& Company, Inc. 


\section{Preface}

Faced with innumerable and perhaps insurmountable problems, a global law of the sea may be a fast disappearing phenomenon. While regretting the disintegration of the world order of the oceans and the seeming inability of nations to agree on a new order, I feel that we may be putting too many of our legal hopes on the rejuvenation of the international law of the sea. It is only realistic to ask what are the alternatives to an international regime for the oceans.

One such alternative, and perhaps a very good one, is the development of regional law of the sea. As an occasional student of the Common Market, I knew that the "Eurocrats" in Brussels have made some surprising, if little known, gains in achieving European regional co-operation in many areas. I thought it possible, therefore, that the European Economic Community had begun to write sea law while in the process of unifying the economies of Europe.

This paper is the result of my investigations of Common Market maritime activities and the possible effect these activities could have in the development of a European system of regional maritime law. I have also investigated very briefly the activities and suggestions of three other European groups and $I$ also report on these findings. There certainly may be law of the sea initiatives taken by still other European groups which I have not considered.

\section{Introduction}

A rapid expansion of economic needs and technical means have combined to threaten the greatest international legal accomplishment, the law of the sea. This challenge to international law is largely a result of national claims to marine resources. Since the Truman Proclamation on the continental shelf in 1945, the nations of the world have sought to bring important and increasingly valuable economic assets-especially oil, gas, and fish-lying in or under the oceans into national jurisdictions. Science and technology have provided the tools which make these underwater resources exploitable.

As a result of national claims, traditional freedoms of the high seas are being eroded by practice and agreement. Competing claims to international waters have led to disputes concerning territorial limits, defense, and pollution. The United Nations has sought to moderate national claims to the seas by formulating new international rules for the oceans. At the first Law of the Sea Conference in Geneva in 1958, participating nations drafted four conventions on the law of the sea (conventions on the Territorial sea and Contiguous Zone, High Seas, Fishing and Conservation of the Living Resources of the High Seas, and Continental Shelf). But the 1958 Conference failed to resolve two pressing legal problems: the outermost legal limits for national claims; first, to territorial waters and, second, to the seabed. The United Nations has often grappled with the twin problems-at the second Geneva Convention in 1960, in the First Committee of 
the General Assembly, and in Ad Hoc and Permanent Committees on the Seabed-but solutions have always eluded the negotiators and diplomats. Thus there are currently no commonly accepted legal standards limiting national territorial seas or national jurisdiction over the seabed. Hypothetically, without a consensus, national claims could carve the international oceans into national "lakes"; the international law of the sea might become a topic of interest only for legal history.

We are, however, not restricted to two alternatives for future ocean law. There is, in fact, a middle ground between the ideal of a new global law for the sea and the threat of a plethora of national maritime jurisdictions. That middle ground is a development of regional systems of maritime law. Regional systems have two distinct advantages. First, they are probably a good deal easier to create than a global law of the sea. Neighboring States may well be able to agree with each other even if they are not able to agree with all of the world's States. And, second, regional law of the sea may be much preferable to national extensions of maritime jurisdiction. Regional law of the sea provides a single set of regional legal rules in place of any number of national sets in the same region. Regional systems of maritime law could simplify economic exploitation and navigation of the seas, as well as provide a better chance for successful control of marine pollution. Regional systems of maritime law might not be as good a goal as a new global international law of the sea, but regional law may be both what we can get and far preferable to the national alternative.

One proof that such regional systems are a workable option for sea law is to be found in the record of the growth of European regional law of the sea. Europeans, and especially the European Economic Community, are on the course of fashioning, step by step, a law for the European seas. The development of European maritime law is a natural outgrowth of the process of European integration which has been proceeding gradually since 1947, when the United States insisted that the European nations work together to administer the Marshall Plan. From the European Coal and Steel Community in 1951, to the Treaty of Rome setting up the Common Market in 1957, to the membership pacts with Britain, Ireland, and Denmark in 1972, the EEC has been slowly but very surely forging a Europe economically united. The Europeans have created important parts of a regional law of the sea in the process of economically uniting the continent.

Regardless of the consequences of the Third Law of the Sea Conference scheduled for 1974 in Santiago, it is important not to underestimate the potential worth of European maritime law. If the attempt at a global solution to the law of the sea problems does succeed, success may be drafted in terms so broad and so permissive of national claims that stricter regional law could be a vital contribution to international order. And if the Santiago Conference fails, as it 
well may, then regional law of the sea may be the most practical alternative to law of the sea anarchy.

\section{The Common Market and Law of the Sea}

Following the successful operation of the Organization for European Economic Co-operation which administered Marshall Plan aid beginning in 1948, and of the European Coal and Steel Community in 1951, advocates of European integration pressed for the inauguration of a European Defence Community and a European Political Community. When the French Assembly rejected the treaty for the EDC in 1954, plans for the EPC were recognized as too ambitious and were scrapped. Instead, proponents of a European union returned to the process of economic integration begun by the OEEC and the ECSC, and sought to achieve complete economic union before returning to plans for political and military integration. On 25 March 1957, the Treaty of Rome was signed by the six member States of the ECSC, France, Italy, West Germany, the Netherlands, Belgium, and Luxembourg, thereby creating the European Economic Community, the so-called Common Market. On 1 January 1973, the six original members of the EEC were joined by three new nations, Great Britain, Ireland, and Denmark.

The Common Market is dedicated to "establish the foundations of an ever closer union among the European peoples". The Rome Treaty directs the EEC to create a Common Market by, inter alia, eliminating internal, and establishing common external, tariffs and other trade barriers, instituting common agricultural and transport policies, and co-ordinating economic policies. ${ }^{1}$ The Common Market has largely accomplished its mission of integrating the economies of Europe and it is generally recognized today that Europe is an economic super-power.

In the process of unifying the European economies, the EEC has taken two important steps towards creating a regional European law of the sea: the EEC Common Fisheries Policy established by the Council of Ministers on 20 October 1970 , and the EEC Commission's decision of 10 September 1970, applying the Treaty of Rome and EEC regulations to the continental shelf. Taken together, the Common Fisheries Policy and the continental shelf decision cover most European activities which exploit the economic resources of the European seas.

The roots of the Common Fisheries Policy are to be found in two articles of the EEC "Constitution", the Rome Treaty of 1957. Article 38, section 1, provides:

The Common Market shall extend to agriculture and trade in agricultural products.

'European Economic Community, Treaty Establishing the European Economic Community and Connected Documents, (Luxembourg: Publishing Services of the European Communities, 1962), pp. 13-18. 
Agricultural products shall mean the products of the soil, of stock-breeding, and of fisheries ...2

Article 52 reads:

. . . restrictions on the freedom of establishment of nationals of a Member State in the territory of another Member State shall be progressively abolished in the course of the transitional period . .

Freedom of establishment shall include the right to engage in and carry on non-wage-earning activities, and also to set up and manage enterprises . . . under the conditions laid down by the law of the country of establishment for its own nationals ....3

Thirteen years elapsed before the Common Market implemented these general provisions and created a common market for fish products and opened national territorial and reserved waters to all Community fishermen. The long delay was a result of the fear of French and Italian fishermen that the relatively more modern and more efficient German, Dutch, and Belgian fishing fleets would dominate both the territorial and reserved waters of Europe and sales to an integrated European fish market. The disparity between the French and Italian fleets and their northern neighbors is well-domonstrated by the 1968 figures below:

\begin{tabular}{|c|c|c|c|}
\hline \multicolumn{4}{|c|}{ FISHING VESSELS 4} \\
\hline Country & Type of Vessel & Number of Vessels & Average Tonnage \\
\hline France & Motor and/or Steam & 13,764 & 21.0 tons \\
\hline Italy & $\begin{array}{l}\text { Motor and/or Steam } \\
\text { Rowing and/or Sail }\end{array}$ & $\begin{array}{l}18,958 \\
27,580\end{array}$ & $\begin{array}{r}10.8 \text { tons } \\
1.3 \text { tons }\end{array}$ \\
\hline Germany & Motor and/or Steam & 1,911 & 95.3 tons \\
\hline Netherlands & $\begin{array}{l}\text { Motor and/or Steam } \\
\text { Rowing and/or Sail }\end{array}$ & $\begin{array}{r}1,403 \\
48\end{array}$ & $\begin{array}{r}68.9 \text { tons } \\
3.0 \text { tons }\end{array}$ \\
\hline Belgium & Motor and/or Steam & 354 & 84.4 tons \\
\hline
\end{tabular}

French and Italian boats are more numerous, but much smaller and boast considerably less average tonnage. Sixty per cent of the Italian fleet is still composed of boats propelled by oars and sail. The disparity between the European fleets is the kind of inequality which encourages protective measures by so many coastal and less modernized fishing States.

Even while recognizing the differences in caliber among national fishing fleets and realizing the problems an EEC policy would have to resolve, the Common Market was unwilling to relinquish its role in the fishing sector to any other

${ }^{2}$ Id. at 47

sId. at 59.

"European Economic Community, "Common Fisheries Policy: Last but not Least", Newsletter on the Common Agricultural Policy, Number 8, November 1970, p. 2. 
agency. In 1961, the Agricultrual Agricultural Minister and Vice-President of the EEC Commission, Sicco Mansholt, vigorously rejected a proposal made on behalf of the British Trawlers' Federation for a European "Fisheries Community". Mansholt declared that the EEC was the proper forum in which to draft and implement a solution to European fisheries problems. He resisted the creation of an institution which might compete with the Common Market by assuming part of the EEC's role as European economic co-ordinator. ${ }^{5}$

Not until July 1966, however, did the Commission, the administrative heart of the EEC, complete a draft of proposals for a common fisheries policy. This 1966 draft suggested free access for all member State fishermen to member State territorial and reserved waters, a free competitive fish market, stabilization of that market, and a Community social policy to aid her fishermen and fishing industry. ${ }^{6}$ The draft was submitted to two EEC consultative groups, the EEC Economic and Social Committee, composed of representatives of business and labor, and the EEC Parliament, composed of representatives of member State parliaments. The Economic and Social Committee and the Parliament did not appreciably alter the Commission's draft proposals which were put into polished form and submitted to the final EEC authority, the Council of Ministers, who received it on 29 May 1968. Three proposals were submitted by the Commission, dealing first with a common structural policy, second with a common organization for the fisheries market, and third with a suspension of common customs tariff duties payable on certain fish. The first of these, the common structural policy, most concerns us. It proposed equal conditions of access and exploitation of territorial and reserved fishing areas, thereby satisfying Article 52 of the Treaty of Rome, and authorizing the EEC to take measures necessary to conserve marine resources. ${ }^{7}$

Considering the drastic changes being considered in relation to the ability of nations to protect their territorial and reserved fishing waters, it is not surprising that the Commission's proposals met heated opposition and adoption of the proposals was delayed through 1968 and 1969. In 1970, the EEC Parliament complained that it feared no common fisheries policy would ever be adopted. ${ }^{8}$ But on 30 June 1970, the Council of Ministers officially adopted a policy permitting (subject to certain transitional periods) equal access for all Community fishermen to all the territorial and reserved waters of member States. ${ }^{\ominus}$ Finally, on 20 October 1970 , the Council issued EEC regulations

\footnotetext{
${ }^{5}$ European Economic Community, Commission, Note d'information, (500/61-F), 4 May 1961. ${ }^{6}$ European Economic Community, Commission, Information Memo: Main Outlines of a Common Fisheries Policy for EEC, (P-39), July 1966.

${ }^{7}$ European Economic Community, Commission, Politique commune de la pêche, (Com 68-288 final), 29 May 1968.

${ }^{8}$ European Economic Community, Bulletin of the European Communities, 3(7) (1970), p. 54.

Ibid., 3(8) (1970), p. 90.
} 
$\# 2141 / 70$ and \#2142/70 respectively establishing a common structure for the fishing sector and a common market for fish products, both coming into effect on 1 February $1971 .{ }^{10}$

The first regulation, establishing a common structure for the fishing sector, directs the member States to assure equal conditions of access and exploitation to all Community fishermen for all those waters over which the member States have sovereignty or jurisdiction. Certain fishing zones of three nautical miles may be restricted to national fishermen for no longer than five years if the coastal population is especially dependent on fishing for its income. A permanent Committee on the Structure of the Fishing Sector is created on which each member State is to have one representative. A representative of the Commission is to chair the Committee which is directed to exchange information about fishing, study the common fishing structure, and aid the Commission in preparing reports. ${ }^{11}$

The EEC Common Fisheries Policy (especially the common structure for the fishing sector) proved to be one of the toughest pills for the States applying for EEC Membership in 1970 to swallow. Only on 12 December 1971, did Great Britain and the Community compromise their differences on the fisheries policy, the last major obstacle to British entry into the Common Market. The original six EEC members agreed to grant the United Kingdom a special ten-year transitional period during which time the British would be permitted to protect their fishing grounds for up to six miles from all their coasts and for up to twelve miles for coastal areas especially dependent on fishing. Ireland and Denmark reached similar accords, but co-applicant Norway would not accept a like agreement and accused the other applicants of "giving-in." 12

No compromise appealed to Norway, as became resoundingly clear when the Norwegians went to the polls to vote on joining the Common Market. On 24-25 September 1972, 53 per cent of the Norwegian voters rejected EEC memtcrship. One of the most important reasons for the Norwegian "No" vote was the common fisheries policy dispute. Norway is Western Europe's greatest fishing nation, doing more fishing than the original six Common Market States combined. And the "No" vote in some of Norway's fishing districts ran as high as 93 per cent. ${ }^{13}$

If open fishing waters and a common market for fish products was too much for the Norwegians to accept, these are becoming working conditions for the nine

\footnotetext{
${ }^{10}$ European Economic Community, Journal officiel des Communauteś européenes: Législation, (13th year, No. L236), 27 October 1970, pp. 1-20.

i1Id. at $1-4$.

${ }^{12 E u r o p e a n ~ E c o n o m i c ~ C o m m u n i t y, ~ " F i s h e r i e s ~ D i s p u t e ~ S o l v e d, " ~ E u r o p e a n ~ C o m m u n i t y, ~ J a n u a r y ~}$ 1972, p. 6.

${ }^{13}$ European Economic Community, "Why Norway Bolted," European Community, December 1972 , p. 13.
} 
Common Market countries. While the common fish market is operational in the original six States and being phased in in the new three States, most territorial waters in the Six are open now and will become fully open to all Community fishermen by 1975 . For the new members and their fishermen, the target date for open territorial waters is $1983 .{ }^{14}$ European Community fishing waters are fast replacing national fishing waters.

The Common Fisheries Policy gives the Common Market considerable momentum to create further regional policies. The Policy establishes the right of the Council to take measures to conserve marine resources. The member States are obliged to co-ordinate their own fishing sectors. The Commission is obliged to report annually to the Council and to the Parliament concerning the common fishing structure. The EEC is authorized to co-ordinate fisheries research and development. ${ }^{15}$

Thus, the EEC is creating a legal regime for regional fishing waters in which Common Market fishermen can fish wherever they desire and where the EEC has the authority to regulate fishing of any nation's fishermen for reasons of marine conservation. The Common Market has the further powers to co-ordinate national fishing policies and to build a Community fishing policy. The Commission has already recommended Community action to improve the structure of the cod fishing industry. The Commission suggests that financial support be made available from the European Agricultural Guidance and Guarantee Fund to modernize this sector. ${ }^{16}$

Besides fish the other chief extractive resource of the ocean lies in the seabed reserves of hydrocarbons. On 28 September 1968, the Council of Ministers asked the Commission to report whether the exploration and exploitation of oil and natural gas on the continental shelf were activities which the Common Market should control. ${ }^{17}$ Two years later, on 10 September 1970 the Commission responded in a memorandum which concluded that the Treaty of Rome and, therefore, EEC regulations do extend to continental shelf activities. The grounds for the Commission's continental shelf decision were that member State assertions of sovereignty over the shelf brought the territory within the limits of the EEC, especially with regard to the exploration and exploitation of hydrocarbons. ${ }^{18}$ Thus, member State nationals have, under Article 52 of the Rome Treaty, freedom to establish throughout the space of the EEC shelf subject to equally applied and increasingly harmonized national laws.

\footnotetext{
${ }^{14}$ European Economic Community, Commission, Common Agricultural Policy, (Brussels: 1972), p. 25.

${ }^{15}$ European Economic Community, Journal officiel des Communautés européennes: Législation, supra note 10, at 2-3.

${ }^{16}$ European Economic Community, Commission, Press Release, (IP -72-17), 25 January 1972.

17Western European Union, Assembly, The Jurdicial Problems of OceanographyToday, (Document 523), 7 October 1970 , p. 6.

${ }^{18}$ European Economic Community, Bulletin of the European Communities, 3(11) (1970), p. 48.
} 
The Commission's continental shelf decision confirms past rulings of the EEC Council. On 28 June 1968, the Council decided that products extracted from nationally-claimed areas of the shelf were to be classed as "products of internal origin" for customs purposes. On 16 October 1969, the Council ruled that German State assistance encouraging off shore oil drilling was subject to EEC regulation if the drilling was carried out on portions the shelf claimed by an EEC member State. ${ }^{19}$

The Common Market has, thus, again moved into the seas and begun to create a regional legal regime in the process of harmonizing and regulating economic activity. There is now what can be called an "EEC Shelf." Within the limits of the Common Market's continental shelf (which is comprised of whatever shelf all the member States claim) the EEC can supervise and regulate activity not only of member States but of any State or corporation.

It is likely that this potential for control of the shelf will be exercised. The Common Market is excessively dependent on the politically volatile Middle East for oil and has sought to create alternative sources of supply. The hydrocarbons lying beneath the North Sea, most of which are now within the jurisdiction of EEC member States and therefore within the jurisdiction of the EEC, form a valuable energy resource. Voices within the Common Market have been raised demanding "an over-all Community-level strategy for crude oil". ${ }^{20}$ On 31 January 1972, the Common Market Council required that member nations communicate to the EEC all investment projects regarding oil, natural gas, and electricity. ${ }^{21}$ Such projects on the EEC shelf are of considerable importance.

It is interesting to note that the emerging European regional law of the sea is not a result of efforts directly aimed at solving legal problems. Instead, regional law is emerging because it is a means to help achieve the goal of harmonized regional activity. The development of European maritime law is a result of a commitment to a European economy in much the same way as in early 19th century America a commitment to a nation-wide economy inspired the federal courts to apply a national law to economic activities and overturn restrictive state legislation. The process of European economic integration has led to the creation of European policies for the economic exploitation of the European sea and, thus, to European regional maritime laws.

A comprehensive European regional law of the sea might, of course, include much more than rules governing the exploitation of fisheries and hydrocarbons and might be stimulated by non-economic factors. There are signs that the pressures of international diplomacy are encouraging the Common Market to formulate European policy for the general range of ocean legal questions. In

\footnotetext{
${ }^{19}$ European Economic Community, "Common Market's Continental Shelf," European Community, November-December 1970, p. 22.

${ }^{20}$ European Economic Community, Bulletin of the European Communities, 5(6) (1972), p. 73.

21Id., 5(3) (1972), p. 95.
} 
February 1972, the EEC Commission reported to the Council about the forthcoming Law of the Sea Conference. The Commission felt that three Conference topics might be of importance to the EEC: the limitation of claims to territorial seas, questions regarding fishing, and the establishment of an international regime for the seabeds and high seas. The Commission noted that the Third World had formed a "bloc" for negotiating purposes and suggested that the Common Market member States and the Commission adopt common policies for law of the sea negotiations. Accordingly, during the seabed negotiations in 1972 at the United Nations, the Community was represented as an observer and representatives of the Commission held co-ordination sessions with member States. ${ }^{22}$

Although the Community has not thus far established a Common Market policy for the up-coming Santiago Conference, it is committed to attempt to do so. Perhaps the Conference will stimulate the emergence of a unified EEC oceans' policy. A massive assembly like the projected Conference encourages bloc voting and the Europeans might well be more influential if they act together and co-ordinate their policy within a Common Market framework. The creation of a Common Market oceans' policy would supplement Common Market economic regulations and would be a third step towards a European sea law.

A fourth area for co-operation might be oceanographic research. In 1969, the EEC Commission tasked its Working Group on the Structure of Scientific Research and Technology to report on possible Community oceanographic co-operation. The Group proposed that the EEC regulate marine pollution and co-ordinate national oceanographic research. Although the Commission stated that it placed special importance on these matters, it went no further at that time than to ask the Working Group to continue to study the matter. ${ }^{23}$

\section{European Law of the Sea Initiatives Outside the EEC}

Proposals for European maritime co-operation or the creation of a European regional system of maritime law have come from sources outside the Common Market and have envisaged agencies other than the EEC to control the European seas. Perhaps the most comprehensive plan for a non-EEC regional "solution" has been proposed by the Bow Group, a British Conservative Party research organization. In 1969, the Bow Group called for the creation of a European "Oceanic Development Commission" to "assume responsibility for creating a regime favorable to an accelerated development of the Sea's physical, chemical, geological and biological resources". ${ }^{24}$ The European Commission would

\footnotetext{
22European Economic Community, "Question écrite No 1201/72 de M. Vredeling." Journal officiel des Communautés européennes, No. C84, 2 August 1972, pp. 6-7.

${ }^{23}$ European Economic Community, Commission, Question écrite No $49 / 69$ de M. Vredeling, 7 June 1969.

${ }^{24 B o w ~ G r o u p, ~ O c e a n-S p a c e-E u r o p e ' s ~ N e w ~ F r o n t i e r, ~(L o n d o n: ~ 1969), ~ p . ~} 20$.
} 
license the exploitation of marine resources, operate research ships, co-ordinate and encourage research activities, found an "Ocean College", regulate marine pollution, and promote conservation of the seas. The Commission would be accountable to a Maritime Parliament composed of politicians, scientists, and representatives of labor and business. The Commission and the Parliament would form a European Maritime Community. Membership in the Community would be open to most Western European countries. The Community would govern the "European Sea-Space," that is all waters to the 4,000-meter isobath or 200 miles from the nearest shoreline whichever gives the greater distance. The European Sea-Space would thus comprise nearly all of the Baltic Sea, the North Sea, the Mediterranean Sea, and the north-east Atlantic Ocean. ${ }^{25}$

The Bow Group argues that only a pooling effort will permit Europe to develop apace the United States ${ }^{26}$ If Europe does not keep abreast, America will reap the greatest benefits from underseas resources. A further argument for the Maritime Community is that a co-ordinated effort will yield the most efficient exploitation of European waters. ${ }^{27}$

Regarding the possible estabishment of an international regime for the oceans, the Bow Group concludes that the problems facing a global regime are too great, but recognizes that:

It may be objected that the regional arrangement we have proposed will face precisely the same problems. But within a region countries do at least have common interests arising from their geographical proximity, and in our own region most countries not only subscribe to the ideal of political and economic integration, but have set up the institutions and procedures by which this might be accomplished. For these reasons we believe that international control and regulation applied regionally would be administratively more tractable and effective. It would also best accord with the principle of equitable distribution that resources recovered, or the proceeds of their sale, should in general be for the benefit of States having the closest access to them. Moreover, the conclusion of regional arrangements does not exclude the co-ordination of activities between one region and another, nor is it inconsistent with world-wide controls where these can be established. ${ }^{28}$

The Bow Group's conclusion that a European regime for the seas is both practical and necessary is an attractive one. But the proposal for a European Maritime Community is subject to the same sort of criticism which was leveled at the proposed European Fisheries Community by Sicco Mansholt in 1961. The EEC is a functioning organization devoted to European co-operation and integration. It is the proper mechanism for implementing European regional economic development. So long as the Common Market is alive and kicking, it

\footnotetext{
${ }^{25}$ Id. at $35-41$ and 48 .

26Bow Group, supra note 24 , at 35 .

${ }^{27}$ Id. at 36.

${ }^{28}$ Id. at 46 .
} 
would likely resist the creation of a competing regime for European economic development. EEC "Sea-Space" is not now so broad as that proposed for the Maritime Community, but Common Market territory already covers many valuable economic areas. Since the Bow Group's study, the EEC has established both the Common Fisheries Policy and the continental shelf decision. Thus, the Common Market has moved to fill the regional gap which the Bow Group detailed. And, of course, in 1973, the United Kingdom joined the EEC. Presumably there is now less incentive for Englishmen to look for non-EEC solutions to European-wide problems. Notwithstanding these reservations, the Bow Group's report stands as an important preview of what a maritime legal regime for Europe might do.

Another group interested in the fate of the European seas has been the Council of Europe, a consultative body established in 1949, and committed to European unity and democracy. Its membership includes most Western European States. On 16 December 1969, the Legal Affairs Committee of the Council's Assembly reported that European nations should "harmonize their national attitudes with a view to solving the (oceanic) problems raised either at UN level or within the 'regional' framework of European co-operation". The Committee proposed that the Council sponsor a Symposium on the Exploration and Exploitation of the Seabed and its Subsoil. ${ }^{29}$

The proposal was adopted and the Symposium was held at Strasbourg, 3-5 December 1970. The most interesting development at the Symposium took place during its fifth sitting when Ambassador Arvid Pardo of Malta, best known for his leadership in the campaign to establish an international seabed regime, advocated "stepping-up regional co-operation, particularly at European level." Pardo proposed the creation of a "European Commission on the Sea", and an intergovernmental organization composed of the member States of the Council of Europe. The Commission would have no economic powers like the EEC or the Bow Group's Maritime Community, but would simply co-ordinate European national marine activities and promote maritime research and education. Further, he suggested the establishment of a "European Institute for Ocean Studies" to investigate European regional oceanic problems. ${ }^{30}$

The Legal Affairs Committee drew several conclusions from the Strasbourg Symposium. First, the public opinion of Europe must be informed about law of the sea problems. Second, Europe must co-operate in oceanographic research and development to keep up with the United States. And, third, there should be

\footnotetext{
${ }^{29}$ Council of Europe, Legal Affairs Committee, Report on the Exploration and Exploitation of the Seabed and the Oceanfloor and the Subsoil thereof, Document 2686, 16 December 1969. ${ }^{30}$ Council of Europe, Consultative Assembly, Report on the Symposium on the Exploration and Exploitation of the Seabed and its Subsoil, Document 2895 Provisional, 15 January 1971, pp. 12-14.
} 
"close legal and political co-operation between the member States of the Council of Europe". 31

On 15 January 1971, the Committee recommended that the Council of Europe's Committee of Ministers convene "as a matter of urgency, an ad hoc committee composed of high government officials and experts with the task of continuously exchanging views on matters relating to conservation and exploitation of the oceans, and in particular on the problems arising in this connection at world-wide and regional level." 32

No action has been taken on the Committee proposal. On 9 October 1972, a motion was presented to the Assembly of the Council of Europe recommending that "the Committee of Ministers make a study of the state of the law of the sea and take, in the light of that study, appropriate measures to co-ordinate European action at the United Nations Conference on the Law of the Sea". The motion has been referred to the Legal Affiars Committee and the Committee on Agriculture. ${ }^{33}$

Thus, though there has been considerable debate on law of the sea in the Council of Europe, no measures have been taken to co-ordinate European policy or law. More than two decades ago the Council was relegated to largely an advisory position and there are no signs that it will now be elevated into a decision-making role. Especially as the Common Market acts to co-ordinate and create European sea law, there is no considerable incentive for Europeans to use the Council of Europe as a law-making vehicle. Actually, the problems faced by the Council are more difficult than those faced by the smaller EEC. The Council's greater numbers include nations which are not inclined to European integration (e.g. Sweden) and nations much at odds with general European opinion about certain law of the sea problems (e.g. Iceland).

Ambassador Pardo's proposal for a European Commission on the Sea is out of step with Common Market preferences to maintain sole competance in this field. Pardo's Commission, though, would have a mandate so restricted to advising and not deciding that it might not prove to be incompatible with Common Market directorship of the economic resources of the European seas. Commission activities promoting oceanographic research and education could complement Community activities. If, however, the EEC moves towards a regime of greater political integration as has been pledged by the 1972 Summit Meeting of Common Market member State presidents and prime ministers, then even European co-ordination of research and education could fall within Community prerogatives.

\footnotetext{
31Id. at 14-16.

${ }^{32}$ Id. at 1-2.

${ }^{33}$ Council of Europe, Consultative Assembly, Motion for a Recommendation on the Law of the Sea presented by Mr. Grieve and Others, Document 3184, 9 October 1972.
} 
A third European group promoting some form of maritime co-operation has been the Western European Union, the military alliance within NATO comprising Great Britain, France, West Germany, Italy, and Benelux. A report presented to the WEU Assembly on 7 October 1970, warned that "if they (the WEU nations) do not join together in considering the juridicial problems of oceanography today, their fear of domination by others in this field may be realized earlier than is now thought possible" ${ }^{34}$ No action, however, was taken in response to this warning. It is doubtful that the WEU is the group best suited to co-ordinating marine policy concerned as it is with strategic questions and not with regional integration.

Altogether, the debates, discussions, and proposals raised outside the Common Market demonstrate that Europeans are awake to the potentials of European regional law of the sea. But it is doubtful that the Europeans will find an existing or a new organization which is better suited to mold a regional system than the EEC. The Common Market has a decided momentum from its successes in economic integration and an administrative establishment both influential and committed to further regional co-operation. The fact that the Common Market has already acted to create regional law governing fisheries and the continental shelf gives the EEC the head start in any competion for the leadership of a regional maritime regime. So long as the Common Market keeps the initiative in co-ordinating national maritime policies and molding reigonal law of the sea, it is unlikely that any other European organization will do much more than discuss and debate the development of European regional law of the sea.

\section{Prospects for a European Regional Law of the Sea}

What does the future hold for a European system of maritime law? It is probable that Common Market control over economic marine activities will be broadened. The Common Fisheries Policy and the continental shelf decision are important assertions of regional authority. A logical next step would be harmonizing national laws regarding Community waters with the end-view creating an EEC law of territorial waters. The energy crisis might encourage the Community to use its avowed powers and govern the exploration and exploitation of the shelf by creating general Community regulations especially for the shelf instead of merely relying on the harmonization of national laws with Community policy.

An expansion of the Common Market would bring more European States within the EEC's regional maritime system. And it is not inconceivable that other European nations will one day join the Common Market. Regardless of future expansion, though, the EEC already includes the four major Western European

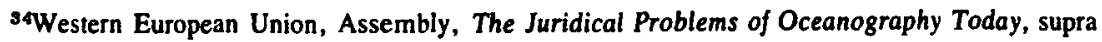
note 17 , at 13 . 
nations-West Germany, France, Italy, and Great Britain-and together with the five small EEC countries, it is fair to say that when the Common Market creates maritime rules, it creates a regional law of the sea.

In the 19th century, the international law of the sea was not much more than European regional sea law spread world-wide by the might of the European empires. Today, European law can make no such automatic claim to international application. Rather, the new States of the 20th century have rebelled at many of the rules of the old European order. This fundamental cleavage between old and new States, between developed and less developed, between North and South is the chief reason why the nations have been unable to agree on a new international order for the oceans. Unlike the old order, a new international regime for the seas cannot be based on "freedom of the seas" since the economic resources of the seas cannot be "freely" exploited without leading to anarchy and inequity. But if a European solution to maritime problems can no longer be the global solution, it can still provide a basis for European regional law. And in the creation of regional international law, Europe not only more efficiently and effectively organizes her seas, but offers a model of regional co-operation for other areas of the globe. 
